\title{
Domestic Waste Management Feasibility Study at Ahmad Dahlan University
}

\author{
Surahma Asti Mulasari, Asep Rustiawan
}

Department of Public Health, Universitas Ahmad Dahlan, Yogyakarta, Indonesia

\begin{tabular}{l}
\hline \hline Article Info \\
\hline Article history: \\
Received Mar 11, 2018 \\
Revised Apr 26, 2018 \\
Accepted Mei 26, 2018 \\
\hline
\end{tabular}

\section{Keywords:}

Campus

Garbage

Waste Management

\begin{abstract}
Garbage dumped untreated into the environment causes health problems. As an educational institution, college should make waste management as a media in educating students in particular, and society. The purpose of this research is to open up new insights into what can be done by Universitas Ahmad Dahlan (UAD) to educate citizens (academics) on the responsibility of managing the environment, especially the waste management practice in college as well as a form of UAD concern for environmental sustainability. This study is a qualitative research which uses road grass analysis approach. Techniques of data retrieval is in-depth interviews with cleaning service, students, employees, canteen vendors, head of BIFAS, vice chancellor II, and the Head of Household. The problems that occurred include: unsorted garbage bins resulting in unpleasant odor, lowered aesthetics, comfort decrease in GARBAGE DUMP, improper behavior of UAD campus residents related to littering, and lack of specific policies related to waste management in campus. Problems of campus trash includes: absence of waste separation process which results in odor, lowered aesthetics, and comfort decrease in GARBAGE DUMP. Another problem is the improper behavior of residents of UAD campus associated with littering, and the lack of specific policies related to campus waste management.
\end{abstract}

Copyright $@ 2018$ Institute of Advanced Engineering and Science. All rights reserved.

\section{Corresponding Author:}

Surahma Asti Mulasari,

Departement of Public Health,

Universitas Ahmad Dahlan,

Jl.Prof. Dr. Soepomo, Janturan, 55164, Yogyakarta, Indonesia

Email: rahmasti@gmail.com

\section{INTRODUCTION}

Garbage is a problem that always appear all the time. The amount and the type of garbage is increasing due to increase in population, technological advances, and socio-cultural changes that make environmental burden to recieve garbage becomes heavy. These problem becomes ever more crucial because people's awareness about garbage disposal is low [1] .

Garbage is solid material discharges from household activities, markets, offices, lodging houses, hotels, restaurants, industry, residual of building material, and used motor vehicle parts. Garbage is a byproduct of human activity that has been used [2]. Garbage left to accumulate can certainly become a problem for health and the environment. Health problems can lead to potential for diseases, whereas for the environment, it can cause contamination by land, air, and water [3].

Garbage cause problems because it is seen as a waste material and environment pollutant, these paradigms must be changed. Based on a study, Bukit Kencana housing at Semarang city is able to process waste of approximately $60 \%$ - $65 \%$ of the volume of 1 to 1.5 tons per day while the rest is transported to TPA Jatibarang. The composition of dry garbage generated is $21.66 \%$ and have a measurable economic value and reached $78.34 \%$ wet garbage which can be used as compost material, mostly for cattle feed [4]. 
The Second Law of thermodynamics states that energy can not be utilized $100 \%$ as there is always a residue (waste). Based on the law, it means that the waste is actually a form of untapped energy (potential energy). Garbage also have economic value. This is proven by the many scavengers, wholesalers, and agents engaged in solid waste. Garbage has economic value because it can be recycled into other forms that is more valuable.

College, as one of the educational institutions should make garbage management as a media in educating students in particular and society in general in the field of sense of responsibility towards the environment. Universitas Ahmad Dahlan (UAD), which has about 14,000 students has the potential to produce garbage from the process of service to students, food and beverage consumption by the entire academic community, and from other academic activities. The garbage produced is certainly not a little amount and it can potentially cause pollution and aesthetics nuisance for the environment around the campus. Based on these ideas, this study will look at the garbage potential that can be caused by UAD and see the extent to which the concept of garbage management has been done by UAD. Expectations from this analysis is to expand the insight and educate citizens (academics) at universities on responsibility of managing the environment, especially the management of the garbage in universities as well as a form of concern from academic community towards environmental sustainability.

\section{RESEARCH METHOD}

This research method was qualitative research, it used grass root analysis approach to find out the main problem of garbage on Campus 1, 2, 3, and 5 of Universitas Ahmad Dahlan. Qualitative research method was used to examine natural objects. Data was collected by triangulation (combined) method, it is inductive in nature, and the results of the research emphasizes meaning rather than generalization, are more descriptive, and the collected data are in the form of words or pictures, so it does not emphasize on on numbers.

This research was conducted in two months (June-July 2014) in Campus 1, 2, 3, and 5 Universitas Ahmad Dahlan, Yogyakarta. The research instrument used was the researchers themselves with the aid of an interview guide. Data analysis was done by coding, perform the presentation as narration and interpret the data.

\section{RESULTS AND ANALYSIS}

Universitas Ahmad Dahlan consists of four (4) active campuses for teaching and learning activities for students, that is campus 1, 2, 3, and 5 of Universitas Ahmad Dahlan. The number of academic employees of the Universitas Ahmad Dahlan in 2014 is 419 people. Whereas the number of non-academic employees of the University of Ahmad Dahlan is 306 people and 85 cleaning service officers. The number of students at the University of Ahmad Dahlan is 12,850 people. The great number of the above-mentioned residents has the potential to produce diverse and huge number of garbage. The Average Output of Garbage Per Day at UAD shown in Table 1.

\begin{tabular}{clc} 
Table & 1. The Average Output of Garbage Per Day at UAD \\
\hline No & \multicolumn{1}{c}{ Campus residents } & $\begin{array}{c}\text { The Average Output of } \\
\text { Garbage Per Day (gram) }\end{array}$ \\
\hline 1 & Students & 246.67 \\
2 & Teacher & 109.1 \\
3 & Employee & 50 \\
& The average per person & 135.26 \\
\hline
\end{tabular}

The average per person of Universitas Ahmad Dahlan campus residents produce 135.26 grams. Calculated per month (30 days), output of garbage will reach 4057.8 grams/person. That figure, when multiplied by the total number of residents of Univesitas Ahmad Dahlan (13,660 people) of waste per person per day amounted to 1,847,651.6 gr. (1.85 ton/day).

The Average Type of Garbage Per Day at UAD shown in Table 2. This type of waste that dominated UAD campus garbage is inorganic garbage. Inorganic garbage comes from food consumption while in campus. Many organic garbage are produced by employees in the form of leftovers. 
Table 2. The Average Type of Garbage Per Day at UAD

\begin{tabular}{llc}
\hline No & \multicolumn{1}{c}{ Type of garbage } & Amount/day $(\%)$ \\
\hline 1. & Leftovers & 66.67 \\
2. & Wrapper leaf & 33.3 \\
3. & Vegetable leftover & 55.56 \\
4. & Paper food wrapper & 55.55 \\
5. & Steroform food wrapper & 11.11 \\
6. & Clear plastic & 55.55 \\
7. & Plastic bag & 66.67 \\
8. & Alumunium foil snack wrapper & 77.77 \\
9. & Snack box & 77.77 \\
10. & Box drinks & 55.55 \\
11. & Small glass mineral water & 100 \\
12. & Mineral water bottle & 44.44 \\
13. & Kerasan plastic & 55.55 \\
14. & Tissue & 66.67 \\
15. & Straw & 66.67 \\
16. & Papers & 22.22 \\
17. & Leaves and plant remains & 33.33 \\
\hline
\end{tabular}

Precentage of Garbage Type in Garbage Dump at UAD shown in Table 3. According to data from garbage dump, it was found that most of the waste generated is plastic waste (various types), followed by paper and organic garbage, which were not very different.

Table 3. Precentage of Garbage Type in Garbage Dump at UAD

\begin{tabular}{llc}
\hline No & Type of garbage dump & amount/day $(\%)$ \\
\hline 1 & Plastic material & 55 \\
2 & Organic garbage & 20 \\
3 & Paper & 25 \\
& Total & 100 \\
\hline
\end{tabular}

Garbage Bins located in UAD shown in Table 4. Infrastructures have been provided by leaders of university in the form of indoor and outdoor garbage bins. Sorter garbage bins are only available in Campus 5 yet.

Table 4. Garbage Bins located in UAD

\begin{tabular}{|c|c|c|c|}
\hline No & Location & Type of Garbage Bins & Quantity \\
\hline \multirow[t]{4}{*}{1.} & Campus 1 & Indoor garbage bins & 51 \\
\hline & & Outdoor garbage bins & 35 \\
\hline & & Temporary garbage bins & 8 \\
\hline & & Total & 94 \\
\hline \multirow[t]{4}{*}{2} & Campus 2 & Indoor garbage bins & 75 \\
\hline & & Outdoor garbage bins & 75 \\
\hline & & Temporary garbage bins & 16 \\
\hline & & Total & 166 \\
\hline \multirow[t]{3}{*}{3} & Campus 3 & Indoor garbage bins & 67 \\
\hline & & Outdoor garbage bins & 81 \\
\hline & & Total & 148 \\
\hline \multirow[t]{4}{*}{4} & Campus 4 & Indoor garbage bins & 22 \\
\hline & & Outdoor garbage bins (sorter) & 8 \\
\hline & & Temporary garbage bins & 7 \\
\hline & & Total & 37 \\
\hline
\end{tabular}

Garbage condition as described above has a potential of becoming UAD's new problems in the form of piled up garbage in temporary garbage bin, unpleasant odor, diminished aesthetics of the campus, unsorted garbage, disturbing amenities of academics, littering, bad condition of garbage bin, insufficient quantity of sorter bins, mixed garbage between organic and inorganic garbage, and littering behavior.

Policy applied in UAD for managing garbage to be disposed in landfills still use the help of third party. The policy is not oriented on managing garbage by $3 \mathrm{R}$ (reduce, reuse, recycle) so it cannot be used to sort out the problems of unmanaged garbage and unsorted garbage based on its material. In other words, UAD still does not have garbage management policy which is in accordance to law number 18 of 2008 (Undang-undang No. 18 tahun 2008) regulating garbage management. 
University is a suitable place to teach and prepare the future generations in order to generate new future leaders and policy makers [5]. This makes university as the appropriate place to embed intellection and behavior concept of environmental awareness including concept and behavior of garbage management.

University can be viewed as business site, study and research site, and main part of society [6]. As a business site, university serves local work force resources. It also interacts with its environment by consuming resources and as result, it produces wastes that have to be assimilated to the environment [7]. As a study and research site, university prepare future leaders to understand environment problems and develop both techniques and strategies to overcome those problems. Universities also give basics of society member relation and have a role in shoving social norms through educational focus, research, and service [8]. Focus on continuity of universities can give examples of behaviors and policies that affect society sectors [9].

Problems regarding garbage have been a global issue which is not only being discussed at government level but is also discussed at many institutions, including those with higher education who should also take part to overcome those problems. University as research, teaching, and policy making institution is suitable to take part in leading and promoting garbage management [10].

Quality of college life depends on its environment condition. Clean class and environment condition can enhance the spirit of studying for students. Academic activities will ensue smoothly in a healthy environment [11]. In 2000, U.S Environmental Protection Agency released enforcement alert explaining that the agency equalized the standard of health and environmental problems for college and university to industrial companies. University also has activities and complex operations with potentially significant environmental impacts [12].

Social and environmental responsibility is recently ignored. A lot of activities in the university need significant control on environmental impacts. These include workshops, use of laboratory, building, maintenance reasons, energy, and materials used. Nowadays, college and university is comparable to complex buildings such as hospital and hotel regarding waste, water, material intake, electricity, and hydrocarbon [13].

Sustainable university is defined as college environment having a healthy, prosperous economy through energy and resources conservation, efficient environmental management, and promoting equality and social justice in concern of exporting those values to society, both locally and globally. University also significantly contributes toward society development as a form of accountability to society, especially, related to youth training and awareness of society in program of sustainability environment management. Therefore, university has to promote developing pattern which is compatible to safety environment, biodiversity, ecological balance, and intergenerational equity. Applied concept for university need to function as a tool for configuring campus and various activities so that academicians are able to fulfill their needs and express their biggest potency in planning and acting in order to maintain long term visions [13].

This initiative involves relation with institution, private sectors, and non-governmental organization to build campus sustainability. Private sectors and governmental institutions could partner with university in research and development sectors, while non-governmental organizations could partner up in organizing workshops and conference about waste management sustainability. This partnership could be held in local, national, or international level. Initiative also covers involvement of university community in all policy making, planning, and also implementation process. People participation in university could be achieved through organizing focus discussion group and interview with representation of stakeholders in order to gain suggestions. Effective participation has to cover the formation of people's representation chosen for work in the system. This initiative could help university on working continuum from regulatory compliance on waste management and sustainability through the use of thinking system and suggestion from key stakeholder [13].

By observing reality, university needs to develop skill and ability through self-development entrepreneurship. Entrepreneurship is a process of forming something different in value by means of using work and time needed, financial risk, included psychology and social aspects, and receiving monetary remuneration, and personal satisfaction. Entrepreneurs are people who transform resources value, labor, material and other production factors into something bigger than its origin, and also people who change, innovate, and do something in novel ways [14].

Empowerment is authorization-giving, defined as assigning people be it classic people or general people as a subject source in development. Empowerment must be viewed in a comprehensive way with empowered people, authorized people, and people as source of development as the final product. And also people are expected to have a better living than usual. One of the ways it can be done is by managing university's waste [14].

There are many ways that could be done by university to manage its waste produced by academicals activity or leftovers. Waste management differs based on type of the waste. Those could be wet garbage (leaf, grass, leftover), dry waste (plastic, paper, bottle), bar garbage (used computer, table, and used chair). Wet garbage such as leaf and grass could be managed into fertilizer so it can fertilize plants or be sold to earn 
money. Plastic garbage could be recycled into useful commodities and could also be sold. Paper garbage could also be recycled using recycling machine and could become an additional income. Bar garbage such as tables and chairs could be renewed and then reused. Waste managerial process could involve representative from society, either from inside or outside the university, in order to gain benefits for both of them [15].

This empowerment should be done for both people inside and outside the university, in order to utilize and manage waste into profit. This empowerment would uplift entrepreneurship's spirit of society so they would have additional income from managed waste and also get involved in environment conservation from waste pollution. Waste managerial program which is done by university would definitely give good effects on the image of university. University as educational service institution must always try to fulfill customer's needs.

Leader of university should form policy toward integrated campus's waste management based on UAD's potentials. These potentials include great number of UAD academicians, number and various type of waste, and strong financial power of UAD. Policy will bind academicians and guests to follow the rules on waste management as instructed and campus's waste management.

\section{CONCLUSION}

A lot of academicians have the potency to produce various and large number of waste. Waste problems, including unsorted waste could result in unpleasant odor, diminished aesthetics, and decline in amenities in temporary garbage bin. Other waste problems are unfavourable behavior of UAD academicians related to littering. And there is still no particular policy on campus's waste management.

\section{ACKNOWLEDGEMENTS}

Thank to cleaning service, students, employees, canteen vendors, head of BIFAS, vice chancellor II, and the Head of Household of Ahmad Dahlan University.

\section{REFERENCES}

[1] Slamet. J. S, "Environmental Health (in Bahasa)", Yogyakarta: Gajah Mada University Press, 2004.

[2] Sucipto. C. D, "Waste Recycling Processing Technology (in Bahasa)", Yogyakarta: Gosyen Publishing. 2012.

[3] Alex. S, "Success in Managing Organic Waste into Organic Fertilizers (in Bahasa)", Yogyakarta: Pustaka Baru Press. 2013

[4] Banowati, "Poverty Reduction of Urban Population through Waste Management Training (in Bahasa)", Journal Komunitas, vol.6, no.1, pp. 159-169, 2014.

[5] Hashim. K. S. H, Mohamed. A.H, Redza, H.Z.M.S, "Developing a waste minimization awareness model through community based movement : A case study of the I I U M Green Team", Malaysia Journal of Society and Space, vol.8. Issue 5, pp. 112-123. 2012.

[6] Johnston. A, White. E, Buckland. H, Parkin. S, Brooke. F, "Reporting for Sustainability: Guidance for Higher Education Institutions", London: Forum for the Future. 2003.

[7] Merkel. L, Merkel. J, Litten, "The sustainability challenge, in Litten, L. and Terkla, D. (Eds), Advancing Sustainbility in Higher Education", San Fransisco, California: Jossey-Bass. 2007.

[8] Rowe. D, "Education for a sustainable future", Science, vol.80, no.317, pp. 323-324. 2007.

[9] Jenks-Jay. N, "Cultivating A Shared Environmental Vision at Middlebury College in Barlett, P F. And Chase, G.W. (Eds), Sustainability on Campus", Cambridge: The MIT Press. 2004.

[10] Simskin. A, G. Nolan, "Enviromental Management Systems in Universities", Enviromental Association for Universities and Colleges. 2004.

[11] Ngozi," Attitude and Wastes Disposal Habits of Students of Nwafor Orizu College of Education Nsugbe", J.Res. Dev, vol.3, no.1, pp. 31-37. 2011.

[12] Dahle. M, Neumayer. E, "Overcoming Barriers to Campus Greening", Int. J. Sustain. High. Educ, vol.2, no.2, pp. 139-160. 2001

[13] Alshuwaikhat. I, H. Abubakar, "An Integrated Approach To Achieving Campus Sustainability: Assessment of The Current Campus Environmental Management Practices", J. Clean. Prod, vol.16, pp.1777-1785, 2008.

[14] Kristanto. M, Prasetiyawati. D, Purwadi, "Implementation of Entrepreneurship Education as a Learning Media through the Utilization of Paud (Paper, Leaf and Plastic) Waste in the City of Semarang (in Bahasa)", Jurnal Penelit. PAUDIA, vol.2, no.1, pp. 43-63. 2013.

[15] Fadhilah. A, Sugiarto. H. Hadi. K, Firmandhani. S.W, Murtini. T.W, Pandelaki. E.E, "Campus Waste Management Study (in Bahasa)", Modul, vol.11, no.2, pp. 62-71. 2011. 


\section{BIOGRAPHIES OF AUTHORS}

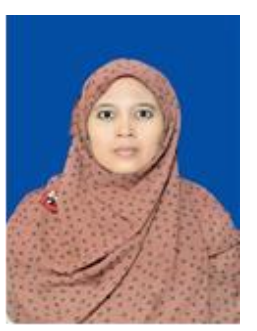

Dr. Surahma Asti Mulasari, S.Si. M.Kes, was born in Yogyakarta on 22 October 1982. The last education of S3 Medicine and Health Sciences UGM. Currently a lecturer in the Departement of Public Health Ahmad Dahlan University, expert of biology and environmental health.

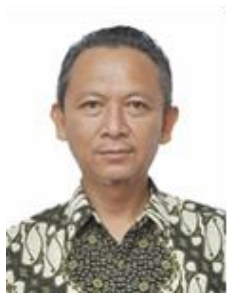

drh. Asep Rustiawan, M.S, was born on Sukabumi 12 May 1962. The last education of S2 Enviroment IPB. Currently a lecturer in the Departement of Public Health Ahmad Dahlan University. The courses are on biomedicine, epidemiology of nutrition, veterinary public health, and healthy tourism. 